\title{
Biochemical and Serological Properties of Purified Flagella and Flagellins of some Pseudomonas spp.
}

\author{
By T. MARTYN WHITESIDE AND MURIEL E. RHODES-ROBERTS* \\ Department of Botany and Microbiology, University College of Wales, \\ Aberystwyth SY23 3DA, UK
}

(Received 19 July 1984; revised 30 October 1984)

\begin{abstract}
Sheared polar flagella of the type strains of monotrichate Pseudomonas aeruginosa and multitrichate $P$. fluorescens and $P$. putida were purified and the sedimentation coefficients of the corresponding flagellins determined by ultracentrifugation; from these values the approximate molecular weights of the major flagellins were calculated to be between 38000 and 43000 , and other estimates based on methionine content also suggested that the range was between 38800 and 43000 . Purified flagellins of these three species, and also $P$. syringae pv. morsprunorum and Pseudomonas sp. ('Vibrio percolans'), were digested with trypsin, and the peptide maps obtained after two-dimensional electrophoresis were compared. Altogether 65 peptide spots were delineated and 15 peptides were found to be common to all five species. The amino acid composition of the purified flagellins of the three type species was found to accord qualitatively and quantitatively with other prokaryote flagellins. Antisera were raised against the three purified flagellins, and tested by the Ouchterlony diffusion plate method against $(a)$ purified homologous and heterologous flagellins, $(b)$ deflagellated cells with sheared flagella and $(c)$ crude sheared flagella of a further 67 test strains and species (mainly Pseudomonas). With either flagella or flagellin antigens the serological reactions were virtually identical, but not all strains of a given species reacted with the relevant antiflagellin antiserum. Rapid species identification using a single antiflagellin antiserum was thus not possible. The flagellar location of the antigenic site(s) was confirmed by two serological methods, including direct immunofluorescent serology.
\end{abstract}

\section{INTRODUCTION}

Bacterial flagella, pili and fimbriae are now under intensive investigation in structural and genetic terms, because these appendages may be important in various tactic phenomena and adhesion, which in turn may affect the virulence of bacteria towards plants or animals. Relevant examples are discussed by Rowbury et al. (1983); they concluded that 'this is a controversial field', an opinion which was reinforced with respect to Vibrio anguillarum (Chart, 1983), Roseburia cecicola (Stanton \& Savage, 1984), Pseudomonas solanacearum (Kelman \& Hruschka, 1973 ) and $P$. phaseolicola (Panapoulos \& Schroth, 1974). Others found that if the motility of $P$. aeruginosa was impaired genetically or immunologically its virulence was reduced (see Holder $e t$ al., 1982, for a review). Furthermore, mice immunized with sheared, purified flagella from virulent strains of $P$. aeruginosa were far less susceptible to challenge doses of this organism than were non-immunized animals. Hence more detailed information concerning Pseudomonas flagella is highly desirable.

Non-motile cells of $P$. aeruginosa are very rare $(<0.2 \%$; Lányi, 1970), and motile cells virtually always possess one polar flagellum; Jessen (1965) found that more than 300 out of 354 strains were exclusively monotrichate. The closely related saprophytic fluorescent pseudomonads typically possess polar multitrichous flagella; one to five fibrils per tuft is characteristic for $P$. putida and three to twenty for $P$.fluorescens (Rhodes, 1958). The flagella of all three species 
are similar in length and wavelength, with approx. two helices with wavelengths of $1 \cdot 8-2 \cdot 2 \mu \mathrm{m}$. How similar they are in biochemical or serological terms is not known because flagellar serotyping is virtually always restricted to sub-speciation within $P$. aeruginosa (Lányi \& Bergan, 1978).

The technical problems involved in obtaining a sufficient yield of polar flagella (yields here of 5-20 mg compared with $50-500 \mathrm{mg}$ from an equivalent wet weight of Proteus cells) are considerable, and the elimination of pili, fimbriae and somatic contaminants is consequently more important. Nevertheless, a study of the biochemical and serological characteristics of purified flagella of the type strains of $P$. aeruginosa, $P$. putida and $P$. fluorescens, together with a few other representative organisms for comparative purposes, was undertaken here. Antisera raised against highly purified flagellins were tested using both flagella filaments and purified flagellins of the three type strains, and the serological reactions towards 67 further strains of Pseudomonas were determined. Amino acid analyses of the three purified flagellins were also carried out, and their relatedness to other flagellins was calculated using the comparative method of Metzger et al. (1968).

\section{METHODS}

Organisms and culture conditions. The strains used were Pseudomonas aeruginosa ATCC 10145 [Pseudomonas Working Party (PWP) No. 1]; P. fluorescens ATCC 13525 (PWP 18); P. putida NCIB 9887 (PWP 25); $P$. syringae pv. morsprunorum D270 from Dr W. J. Dowson, Cambridge University; Pseudomonas sp. NCIB 8193 deposited as 'Vibrio percolans' (PWP 10); Xanthomonas campestris NCPPB 13528 (PWP 31), and various other strains listed in Table 5; these were from the Rhodes Collection or those issued to the Pseudomonas Working Party (Sneath \& Collins, 1974). The two media used had the following compositions ( $\left(\mathrm{g}^{-1}\right.$ deionized water): (1) nutrient broth (NB): Oxoid bacteriological peptone L37, 5; Oxoid Lab Lemco L29, 5; NaCl, 5; adjusted to pH 7.2. (2) Yeast extract broth (YEB): Oxoid bacteriological peptone, 10; Oxoid yeast extract $\mathrm{L} 20,3 ; \mathrm{NaCl}, 5$; adjusted to pH 7.2. For solid media Oxoid agar no. 3 was added to give a final concentration of $1.3 \%(w / v)$, and $2.0 \%(w / v)$ sucrose YEB enhanced the growth of some phytopathogens. Chemically defined media gave much lower numbers of flagellate cells and so were abandoned.

Detection of motility and flagellation. Motility in liquid cultures was checked by the hanging-drop technique, and the detailed flagellation was determined by examination of silver-plated preparations from NA/water slopes using the staining and light microscope method of Rhodes (1958).

Isolation of flagella. Late exponential or early stationary phase growth of cells incubated for $3-5 \mathrm{~d}$ at $14^{\circ} \mathrm{C}$ on NA or YEA was harvested at room temperature in PBS $(0.9 \%, \mathrm{w} / \mathrm{v}, \mathrm{NaCl}$ in $0.02 \mathrm{M}$ phosphate buffer $\mathrm{pH} 8.1)$. The organisms were removed gently to minimize breakage of flagellar filaments, suspended in PBS, and warmed to 35$40^{\circ} \mathrm{C}$ for $15 \mathrm{~min}$ with gentle agitation, prior to centrifugation at $8000 \mathrm{~g}$ for $20 \mathrm{~min}$. After two more washes in warm PBS to remove exocellular polysaccharides, the concentrated cell suspensions were deflagellated by shaking for 60-90 min (av. 10 strokes $\mathrm{s}^{-1}$ ) on a Griffin shaker. The deflagellated cells were removed by centrifugation at $12000 \mathrm{~g}$ for $30 \mathrm{~min}$ at $3{ }^{\circ} \mathrm{C}$, and the sedimented cells resuspended in PBS and centrifuged twice more to recover flagella trapped in the cell mass; pooled supernatants were then centrifuged at $75000 \mathrm{~g}$ for $2 \mathrm{~h}$ at $3{ }^{\circ} \mathrm{C}$ and the sedimented flagella subsequently allowed to resuspend overnight at $4{ }^{\circ} \mathrm{C}$ in $3 \mathrm{ml} 0.02 \mathrm{M}$-borate buffer $\mathrm{pH} 8 \cdot 5$. This procedure was repeated until the final pellet of flagellin was transparent and contained less than $0 \cdot 1 \%$ (wet weight) viable cells. This was determined using the drop count method of Miles et al. (1938) and calculating cell weight by assuming that one cell weighed $10^{-12} \mathrm{~g}$. The final pellet, with counts less than 2000 organisms $\mathrm{ml}^{-1}$, was suspended in $3 \mathrm{ml}$ membrane-filtered distilled water. Completely bacteria-free preparations of native flagella were never obtained, even after more intensive centrifugation, and so $<0.1 \%$ wet wt cells per flagella sample was finally regarded as acceptable. Great care was taken to avoid the introduction of microbial cells during the subsequent purification procedures: e.g. all the buffer and ammonium sulphate solutions were membrane-filtered.

Preparation and purification of flagellins. The $3 \mathrm{ml}$ suspensions (above) were diluted to $25 \mathrm{ml}$ with distilled water and the $\mathrm{pH}$ was slowly adjusted to $2 \cdot 0$ by dropwise addition of $1.0 \mathrm{M}-\mathrm{HCl}$; acid-induced dissociation of flagella into flagellin was facilitated by incubation at $40-42^{\circ} \mathrm{C}$ for $30 \mathrm{~min}$. The 'pH 2.0 insoluble material' was removed by centrifugation at $30000 \mathrm{~g}$ for $90 \mathrm{~min}$ at $20^{\circ} \mathrm{C}$. The flagellin was then precipitated from the supernatant by adjusting it to $\mathrm{pH} 8.0$ using $0.1 \mathrm{M}-\mathrm{NaOH}$, and then adding a saturated solution of recrystallized ammonium sulphate (the original crystals contained numerous yeast cells) to give various final degrees of saturation values. This acid-dissociation followed by ammonium sulphate precipitation procedure was repeated several times, retaining a narrower range of the ammonium sulphate precipitate each time, i.e. flagellin sequentially precipitated using $0-60 \%, 10-60 \%, 45-60 \%$, and finally $48-58 \%(\mathrm{w} / \mathrm{v})$ ammonium sulphate. This procedure was essential to reduce anthrone-positive material from $25 \%(w / w)$ to $0.2-0.4 \%(w / w)$, and to eliminate 3-5 bands of minor proteins detected by SDS-PAGE. The final ammonium sulphate precipitate was desalted by dialysis against five 
changes of sterile distilled water for $16-20 \mathrm{~h}$ until free of ammonia (tested using Nessler's reagent). The final matcrial showed only a single band after electrophoresis on $5 \%(\mathrm{w} / \mathrm{v})$ polyacrylamide geis containing $1 \%$ SDS, after running at $10 \mathrm{~mA}$ for $8 \mathrm{~h}$ and then staining the geis with Coomassie brilliant blue (Shapiro et al., 1967). Such purified flagellins were freeze-dried.

Further tests for purity. Carbohydrate contamination was tested for using the anthrone Molisch reaction (Snell \& Snell, 1953); the method of King (1932) was used to determine phosphate content; the presence of tryptophan, a marker for extraneous protein, was checked using the Hopkins-Cole (Hopkins \& Cole, 1901) reaction.

Trypsin hydrolysis. Following the method of Emerson \& Simon (1971), lyophilized flagellin samples were treated with performic acid (to eliminate artifacts arising from oxidation of methionine during the drying periods), at a concentration of $2 \cdot 0^{\circ} \mathrm{o}(\mathrm{w} / \mathrm{v})$ in $0.02 \mathrm{M}$-phosphate buffer $\mathrm{pH} 8 \cdot 1$, and digested with an equal volume of $0 \cdot 04 \%(\mathrm{w} / \mathrm{v})$ trypsin (BDH) plus one drop of toluene. Digestion was complete after $20 \mathrm{~h}$ at $25^{\circ} \mathrm{C}$ (Enomoto \& Iino, 1966). Each sample $(300 \mu \mathrm{g})$ was then chromatographed two-dimensionally as follows: $(a)$ in the first dimension by low-voltage electrophoresis on Whatman $3 \mathrm{MM}$ paper at $\mathrm{pH} 1 \cdot 5$, using formic acid/glacial acetic acid/water $(15: 5: 80$, by vol.) at $15 \mathrm{~V} \mathrm{~cm}^{-1}$ for $5 \mathrm{~h} \mathrm{at} 0^{\circ} \mathrm{C}$, the electrophoretograms then being air-dried; $(b)$ in the second dimension by descending solvent chromatography with freshly prepared $n$-butanol/glacial acetic acid/water $(200: 30: 75$, by vol.) for $15 \mathrm{~h}$ at 20 " $\mathrm{C}$. The air-dried chromatograms were sprayed with $0.5 \%(\mathrm{w} / \mathrm{v})$ ninhydrin and the colour allowed to develop for $20 \mathrm{~min}$ at $65-70^{\circ} \mathrm{C}$. Thus a characteristic peptide fingerprint map of each flagellin was obtained.

Tests for specific amino acids. Small samples of the flagellins were spot tested for the presence of specific amino acids; ethanolic nitroso-2-naphthol was used to test for tyrosine (Gerngross et al., 1933), the diazo reagent of Mann \& Leon (1953) for histidine, and the Sakaguchi reaction for arginine (Carver et al., 1953).

Amino acid analysis. The determination of the amino acid compositions of the purified, lyophilized $P$. aeruginosa, $P$. fluorescens and $P$. putida flagellins was carried out by $\mathrm{Dr} W$. A. Weetman, Department of Experimental Pathology, University of Birmingham, UK. The samples were hydrolysed in constant boiling $6 \mathrm{M}-$ $\mathrm{HCl}$ under vacuum at $110^{\circ} \mathrm{C}$ for $24 \mathrm{~h}$ and then analysed on a Locarte (London, UK) amino acid analyser using ninhydrin as the detection reagent.

Determination of sedimentation coefficients by ultracentrifugation. A sample of flagellin $\left(7 \mathrm{mg} \mathrm{ml}^{-1}\right)$ in either $0 \cdot 2 \mathrm{M}$ citrate buffer $\mathrm{pH} 2.2$ or in $0.1 \%(\mathrm{w} / \mathrm{v})$ SDS in $0.2 \mathrm{M}$-phosphate buffer $\mathrm{pH} 7 \cdot 1$ was centrifuged at $59780 \mathrm{~g}$ at $20^{\circ} \mathrm{C}$ in a Beckman Model E analytical centrifuge. The bar angle was altered when necessary, and photographs of the positions of the peaks were taken at predetermined time intervals by employing the Schlieren optical system (exposure, $20 \mathrm{~s}$ ). Measurements from the photographic plates were made with a Gaertner micrometer, and uncorrected sedimentation coefficients calculated using the standard formula. From these values the approximate molecular weights were determined.

Serological studies. Antiflagellin antisera against the three species, $P$. aeruginosa, $P$. fluorescens and $P$. putida were kindly prepared by Dr M. B. McIllmurray of the Wellcome Research Laboratories, Beckenham, Kent, UK. High titres were obtained in mouse ascitic fluid, and each antiserum tested against (a) purified homologous and heterologous flagellins; $(b)$ cells deflagellated by shearing (centrifuged once only); $(c)$ the crude preparation of sheared flagella. Immunodiffusion through Ouchterlony plates containing a $2-4 \mathrm{~mm}$ depth of $0.75 \%$ (w/v) Oxoid Ionagar No. 2 in $0.9 \%(\mathrm{w} / \mathrm{v})$ saline in $0.05 \mathrm{M}$-phosphate buffer $\mathrm{pH} 8.1$ proved to be the most reliable technique for demonstrating the antigen-antibody precipitin reactions. The prepared plates were incubated in sealed bags at $37^{\circ} \mathrm{C}$ for 1-3 d. Precipitation was usually optimal after $48 \mathrm{~h}$, and intensified after overnight refrigeration at $0{ }^{\circ} \mathrm{C}$. A positive control was included in every plate, and tryptic digests of the flagellins showed no precipitates when tested with homologous or heterologous antiflagellin antisera. Crude flagella and flagellin preparations from a further 67 strains (listed in Table 5) were similarly screened.

Proof of the flagellar location of the antigenic site. Further proof that the flagellins were the antigens in the immunodiffusion plates was obtained by running the flagellin sample electrophoretically on $7 \cdot 5 \%(w / v)$ polyacrylamide gel in the absence of SDS. Such gel strips were then halved longitudinally; one half was stained with Coomassie blue to locate the flagellin, and the other half placed on a $0 \cdot 75 \%(w / v)$ Ionagar plate and allowed to react against a channel of homologous antiflagellin antiserum. The two halves were then realigned and compared.

Immunoftuorescent serology. Air-dried smears of washed cells of $P$. putida were treated with specific anti-flagellin antiserum in a moist atmosphere at $37^{\circ} \mathrm{C}$ for $24 \mathrm{~h}$, washed for $8 \mathrm{~h}$ in flowing $0.9 \%(\mathrm{w} / \mathrm{v})$ saline. After re-drying the smear, rabbit anti-mouse immunofluorescent serum was applied and adsorption effected during incubation in a moist atmosphere for $24 \mathrm{~h}$ at $37^{\circ} \mathrm{C}$. After re-washing with $0.9 \%(\mathrm{w} / \mathrm{v})$ saline for $8 \mathrm{~h}$, the specifically stained flagella were located by light-ground UV microscopy following the techniques of Walker et al. (1971).

\section{RESULTS}

Motility and flagellation. The rapid darting motility of all 67 isolates of pseudomonads used here was constantly confirmed in hanging-drop preparations, and exactly polar flagella resolved in silver-plated preparations. $P$. aeruginosa was virtually always monotrichate (rarely 2 polar 
Table 1. Flagellar wavelengths of polarly flagellate prokaryotes

Values for air-dried bacteria were determined from light microscope micrographs of silver-plated bacteria and compared with the wavelengths of detached, purified, self-assembled flagella suspended in $50 \%(w / v)$ ammonium sulphate. Values are the means of 50-80 measurements.

\begin{tabular}{|c|c|c|}
\hline \multirow[b]{2}{*}{ Organism* } & \multicolumn{2}{|c|}{ Flagellar wavelength $(\mu \mathrm{m})$} \\
\hline & Air-dried cells & $\begin{array}{l}\text { Self-assembled } \\
\text { filaments }\end{array}$ \\
\hline P. aeruginosa & & \\
\hline $\begin{array}{l}\text { ATCC } 10145 \text { (PWP 1) } \\
\text { P. fluorescens }\end{array}$ & $1 \cdot 8-2 \cdot 2$ & 0.77 \\
\hline $\begin{array}{l}\text { ATCC } 13525 \text { (PWP 18) } \\
\text { P. putida }\end{array}$ & $1 \cdot 8-2 \cdot 0$ & 0.9 \\
\hline $\begin{array}{l}\text { NCIB } 9887 \text { (PWP 25) } \\
\text { P. stutzeri }\end{array}$ & $1 \cdot 8-2 \cdot 2$ & 0.88 \\
\hline $\begin{array}{l}\text { ATCC } 17592 \text { (PWP 120) } \\
\text { P. syringae pv. }\end{array}$ & $1.8-2.0$ & 0.68 \\
\hline $\begin{array}{l}\text { morsprunorum D270 } \\
\text { Xanthomonas campestris }\end{array}$ & $1.5-1.8$ & 0.68 \\
\hline NCPP 13528 (PWP 31) & $1.6-1.8$ & Insufficient yield \\
\hline $\begin{array}{l}\text { Pseudomonas sp. ('Vibrio } \\
\text { percolans') NCIB } 8193 \\
\text { (PWP 10) }\end{array}$ & $2 \cdot 7-3 \cdot 1$ & $\begin{array}{l}\text { Short units failed } \\
\text { to aggregate }\end{array}$ \\
\hline
\end{tabular}

* PWP, Pseudomonas Working Party (Sneath \& Collins, 1974)

Table 2. Comparison of the number of flagella peptides shared by each pair of five polarly flagellate bacteria, revealed by comparing their peptide maps

\section{P. fluorescens ATCC 13525}

P. putida NCIB 9887

P. aeruginosa ATCC 10145

$P$. syringae pv. morsprunorum D270

Pseudomonas sp. ('Vibrio percolans') NCIB 8193

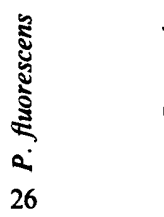

22

18

18

21

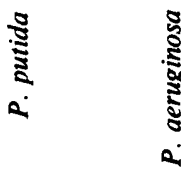

38

19

15

21
27

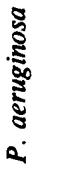

19

18

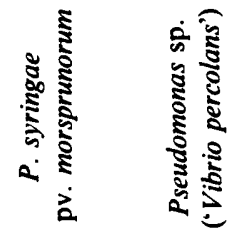

31

18

30

flagella); $P$. putida possessed 1-5 flagella, although monotrichy was rather common; $P$. fluorescens had 3-20 flagella (3 rather frequently). The wavelengths of some native flagella are given in Table 1, together with the wavelengths of detached ammonium-sulphate-aggregated flagella. Why the values of the latter are approximately only half those of the air-dried cells is not known. The shorter and more loosely coiled flagella of Pseudomonas sp. ('Vibrio percolans') with a wavelength of $2.7 \mu \mathrm{m}$ yielded short fibrils which would not aggregate, perhaps due to traces of flagellin polymerization inhibitors recently reported by Ikeda et al. (1984) for the short-flagellum mutant of Salmonella typhimurium.

Tryptic digests and peptide mapping. Two-dimensional separation of the tryptic hydrolysates of the flagellins yielded a characteristic 'fingerprint' or peptide map of peptides for each flagellin; 5 flagellins were thus carefully compared and a comparative summary of their peptide maps is presented in Table 2. Only spots appearing in the same positions on at least 3 of the 5 replicates obtained for each strain were recorded; a total of 65 peptide spots was thus marked. The number of peptides which consistently appeared for each species was: $P$. aeruginosa, $27 ; P$. fluorescens, 26; $P$. putida, $38 ;$ P. syringae pv. morsprunorum, 31 ; Pseudomonas sp. ('Vibrio percolans') 30 . A 
Table 3. Amino acid composition of the flagellins of three type strains of Pseudomonas

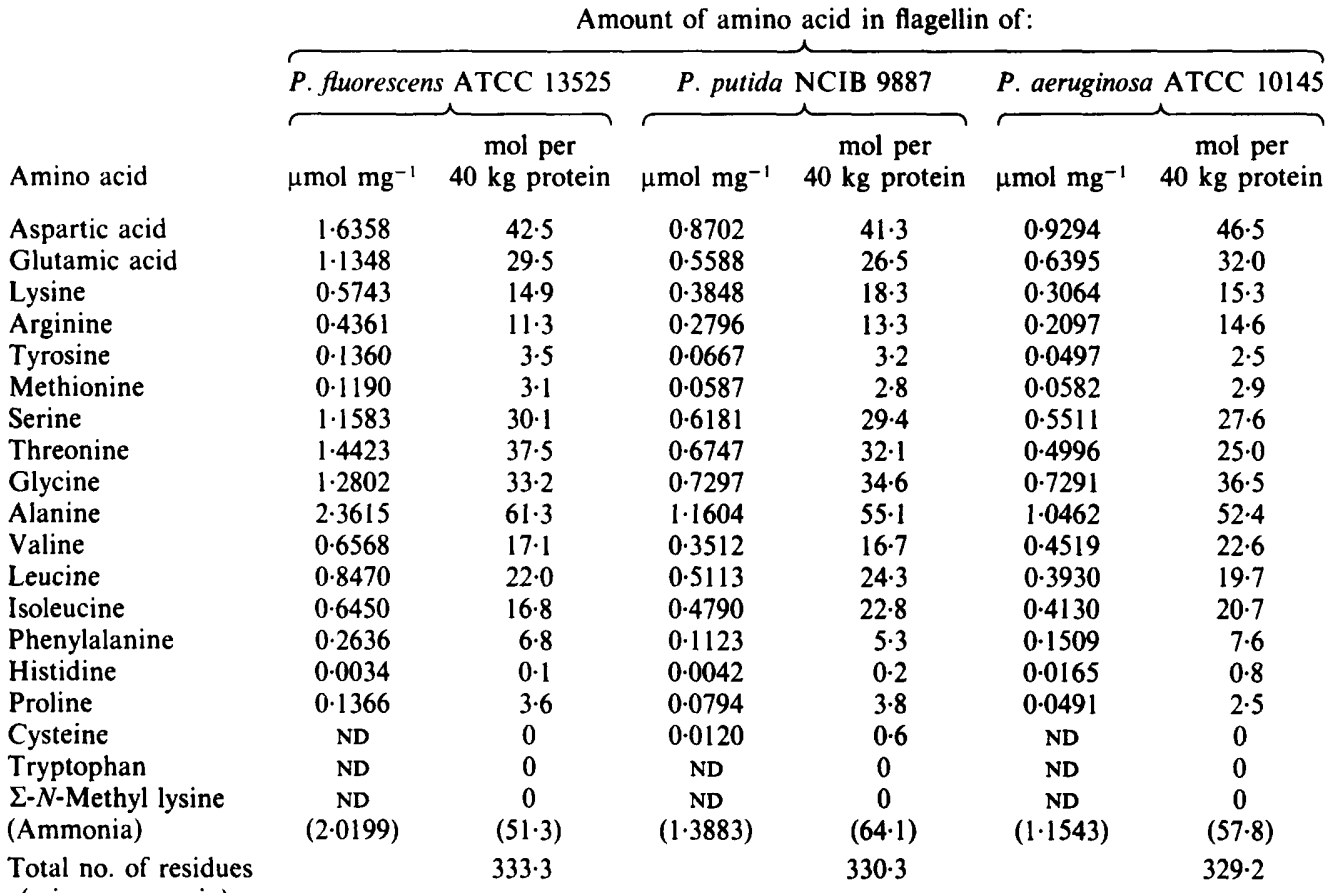

ND, Not detected.

Table 4. Sedimentation coefficients (Svedberg units) and estimated molecular weights for Pseudomonas flagellins

Flagellin concentration was $7.0 \mathrm{mg} \mathrm{ml}^{-1}$ in (a) $0.2 \mathrm{M}$-citrate buffer $\mathrm{pH} 2.2$, and (b) $0.1 \% \mathrm{SDS}$ in $0.2 \mathrm{M}$ phosphate buffer $\mathrm{pH} 7 \cdot 1$. Approximate molecular weights (which should be regarded as the lower limit of the true values), calculated from $\mathbf{S}$ values, are also given.

\begin{tabular}{|c|c|c|c|c|c|}
\hline \multirow[b]{2}{*}{ Source of flagellin } & & \multicolumn{2}{|c|}{ Main component } & \multicolumn{2}{|c|}{ Minor component } \\
\hline & & $S$ value & Mol. wt & $\mathbf{S}$ value & Mol. wt \\
\hline P. aeruginosa ATCC 10145 & (a) & $2 \cdot 35$ & 38000 & 11.87 & 180000 \\
\hline P. putida NCIB 9887 & (a) & 2.43 & 40000 & ND & - \\
\hline P. fluorescens ATCC 13525 & (a) & $2 \cdot 51$ & 41000 & $12 \cdot 39$ & 220000 \\
\hline & (b) & $2 \cdot 58$ & 41000 & $11 \cdot 08$ & 150000 \\
\hline $\begin{array}{l}P \text {. syringae pv. } \\
\text { morsprunorum D270 }\end{array}$ & (a) & $2 \cdot 86$ & 43000 & $14 \cdot 57$ & 250000 \\
\hline
\end{tabular}

ND, Not detected.

total of 15 peptides were common to all five species, and the number of peptides shared by each pair of species is shown in Table 2.

Animo acid analysis. The amino acid data (supplied by Dr W. A. Weetman) for 3 Pseudomonas flagellins are given in Table 3, which shows that all three species had high proportions of aspartic acid, glutamic acid, threonine, alanine and glycine, and small amounts of tyrosine, phenylalanine, methionine, proline and histidine. Tryptophan and $\Sigma$ - $N$-methyl lysine (peculiar to some Salmonella spp.; Ambler \& Rees, 1959) were never detected. A small amount $(0 \cdot 17 \%$, $w / w)$ of cysteine was found in the $P$. putida flagellin.

Determination of sedimentation coefficients by ultracentrifugation. The results of ultracentrifugation of acid-dissociated purified flagellin at $\mathrm{pH} 2.2$ are detailed in Table 4 . Exact molecular weights could not be calculated here because no accurate estimations of the partial specific volumes of the proteins, nor of their diffusion constants in the buffers used, were available. The 
Table 5. The reactions of 67 bacterial isolates towards antisera raised against purified flagellins of $P$. aeruginosa, $P$. fluorescens and $P$. putida

Reactions were determined by the Ouchterlony diffusion technique, with both crude sheared fiagella (Fla) after one centrifugation or purified flagellins (Fln) as antigens. Trypsin-digested control flagellins showed no serological reactions.

\begin{tabular}{|c|c|c|c|}
\hline & \multicolumn{3}{|c|}{$\begin{array}{c}\text { Reaction of antisera prepared against } \\
\text { flagellins of :* }\end{array}$} \\
\hline & $\begin{array}{l}P . \text { aeruginosa } \\
\text { ATCC } 10145 \\
\text { (PWP 1) }\end{array}$ & $\begin{array}{l}\text { P. fluorescens } \\
\text { ATCC 13525 } \\
\text { (PWP 18) }\end{array}$ & $\begin{array}{c}\text { P. putida } \\
\text { NCIB } 9887 \\
\text { (PWP 25) }\end{array}$ \\
\hline ecies & Fla Fln & Fln & Fla \\
\hline
\end{tabular}

P. aeruginosa ATCC 10145 (PWP 1)

P. aeruginosa ATCC 10145 (PWP 85)

$P$. aeruginosa NCTC 5940

$P$. aeruginosa Rhodes 20

$P$. aeruginosa Rhodes 21

$P$. aeruginosa Rhodes $24 / 2$

$P$. aeruginosa Rhodes $282 / 9$

$P$. aeruginosa $\mathrm{Rhodes} 282 / 11$

$P$. aeruginosa Rhodes $282 / 14$

$P$. aeruginosa Rhodes strains $24 / 1,282 / 1,2,3,4,5,6$, $7,8,10,12,13$

P. fluorescens ATCC 13525 (PWP 18)

$P$. fluorescens $\mathrm{R}$ hodes strains $4 / 3,8 / 7,9,12 ; 12 / 3$,

22/1, 22/2, 23/5, 26/3, 45

$P$. putida NCIB 9887 (PWP 25)

P. putida NCIB 9887 (PWP 86)

P. putida NCIB 9887 (Rhodes 192/1)

P. putida NCIB 9887 (Rhodes 192/2)

$P$. putida Rhodes 41

$P$. putida Rhodes T207

$P$. putida Rhodes T202

$P$. putida $\mathrm{R}$ hodes T206

$P$. putida Rhodes $43 / 2$

P. putida Rhodes $43 / 3$

P. putida Rhodes $43 / 4$

$P$. putida Rhodes 34

$P$. putida Rhodes strains $9 / 2,9 / 4,15 / 4,15 / 5,25 / 1$,

$32,35 / 2,42 / 3,43 / 1,44,56 / 1, \mathrm{KB1}, \mathrm{D} 244, \mathrm{~T} 200$

$P$. syringae pv. morsprunorum $\mathrm{D} 270$

P. stutzeri ATCC 17592 (PWP 120)

$P$. lemoignei NCIB 9947 (PWP 123)

P. stizolobii NCPPB a450

P. cepacia (multirorans) ATCC 17759

(PWP 88)

P. acidotorans NCIB 9681 (PWP 72)

$P$. pseudoalcaligenes NCIB 9946 (PWP 122)

Pseudomonas sp. ('Vibrio percolans')

NCIB 8193 (PWP 10)

Xanthomonas campestris NCPPB 13528 (PWP 31)

Proteus rulgaris Rhodes 18E

$*+$, Definite arc of precipitation: $+^{m}$, definite arc of precipitation plus arc representing a minor antigen $;(+)$, faint precipitate probably due to non-flagellar impurities; sl, slight precipitate; PWP, Pseudomonas Working Party strain (Sneath \& Collins, 1974).

approximate molecular weights suggested by the main peak flagellins were between 38000 and 43000 , based on the calculation of Weibull (1948) that an S value of 2.4 is approximately equivalent to a molecular weight of 41000 , but that this should be regarded as the lower limit of the true value. 
Serological studies. Each of the three anti-flagellin antisera prepared in mice against highly purified flagellins of $P$. aeruginosa, $P$. fluorescens and $P$. putida as antigens, produced a single distinct arc of precipitation when tested against homologous flagellins ( $3 \mathrm{mg}$ flagellin $\mathrm{ml}^{-1}$ in the test well), or against crude sheared flagella, in the Ouchterlony diffusion plates. Heterologous flagellins or flagella showed no such reactions; sheared homologous cells sometimes showed weak reactions. This was possibly due to residual flagellar stumps on the sheared cells, although in one flagella regeneration experiment with $P$. aeruginos a the majority of the deflagellated cells failed to regenerate flagella; the few which did so produced flagella $0.5 \mu \mathrm{m}$ long after $30 \mathrm{~min}$, $1.0 \mu \mathrm{m}$ long after $60 \mathrm{~min}$, and $2.5 \mu \mathrm{m}$ long after $150 \mathrm{~min}$, compared with flagella $3.5 \mu \mathrm{m}$ long on the control cells.

The results of similarly testing crude (sheared) flagella preparations and partially purified flagellins derived from 67 additional test isolates are summarized in Table 5. It is evident that each of the three species was not homogeneous; blind testing of duplicates of both $P$. putida and $P$. aeruginosa, however, yielded identical results. With either flagella or flagellin as antigens for a given strain, the serological results were virtually identical.

Proof of the flagellar location of the antigenic site. When purified flagellin preparations were separated electrophoretically on SDS-free polyacrylamide gels, and then the longitudinally halved gels treated with Coomassie brilliant blue on the one half and antiflagellin antiserum on the other, a single antigen-antibody precipitin line was found to correspond exactly with the position of the band of flagellin protein on the other half of the gel strip.

Immunofluorescent serology. P. putida cells stained with specific immunofluorescent antiflagellin antiserum showed a rather thick single polar flagellum in the UV light microscope. Aggregation of fibrils was suspected.

\section{DISCUSSION}

The technique of repeated acid dissociation and ammonium sulphate precipitation eventually yielded purified Pseudomonas flagellins which migrated as a single protein on $7.5 \%(\mathrm{w} / \mathrm{v})$ polyacrylamide gels. Removal of carbohydrate impurities from flagellins was never effected here using DEAE-cellulose fractionation procedures. Possible contamination of our cysteinecontaining $P$. putida flagellin caused concern because $P$. aeruginosa pili are known to contain cysteine (Paranchych et al., 1979). However, our serological and ultracentrifugation studies failed to reveal contaminating proteins, and our $0.17 \%(w / w)$ cysteine content may be compared with the 0.54-0.75\% cysteine-cystine content of Proteus and Bacillus flagellins 'of highest purity' reported by Kobayaishi et al. (1959): cysteine was also found by Montie et al. (1982) in the purified flagella preparations of $P$. aeruginosa. Finally, Paranchych et al. (1979) convincingly purified the polar pili of $P$. aeruginosa strains PAO and PAK as single polypeptides of molecular weight 18700 and 18100 , respectively, and no such molecules were detected in our flagellins.

Ultracentrifugation of the $P$. aeruginosa and $P$. fluorescens flagellins for molecular weight determinations resulted in a main peak and a smaller, heavier peak which diffused rapidly. This component had an uncorrected $S$ value approx. fivefold greater than that of the main flagellin, and may represent an aggregate of five protein units, in accord with the observations of Lowry \& Hanson (1965) who found two types of fine structures in $P$. fluorescens flagella, one with ten helices, and the other with five longitudinal helical rows of fibrils.

It was not possible to determine the exact molecular weights of the flagellins, but uncorrected sedimentation coefficients suggested values between 38000 and 43000 (see Table 4). Assuming a molecular weight of 40000 , the number of lysine and arginine residues in our flagellins was 29 30 for $P$. aeruginosa, 26-27 for $P$. fluorescens and 31-32 for $P$. putida, all in good agreement with the number of peptides produced after tryptic digestion (Table 2). When the methionine content was used to calculate the minimum molecular weight (assuming three residues per mol protein), of flagellins, 41200 was calculated for $P$. aeruginosa flagellin, 38800 for $P$. fluorescens and 43000 for P. putida. 
Table 6. Comparison of the chemical similarities between different bacterial flagellins

Data are expressed as the difference index of Metzger et al. (1968) calculated from amino acid data obtained from the references indicated.

\begin{tabular}{|c|c|c|c|c|}
\hline & $\begin{array}{l}P . \text { fluorescens } \\
\text { ATCC } 13525\end{array}$ & $\begin{array}{c}P . \text { putida } \\
\text { NCIB } 9887\end{array}$ & $\begin{array}{l}P . \text { aeruginosa } \\
\text { ATCC } 10145\end{array}$ & Reference \\
\hline P. fluorescens ATCC 13525 & 0 & & & This study \\
\hline P. putida NCIB 9887 & $5 \cdot 1$ & 0 & & This study \\
\hline P. aeruginosa ATCC 10145 & $8 \cdot 1$ & $7 \cdot 1$ & 0 & This study \\
\hline ( $P$. aeruginosa $\mathrm{PAK}$ pili) & $17 \cdot 7$ & $12 \cdot 7$ & $18 \cdot 4$ & Paranchych et al. (1979) \\
\hline (P. aeruginosa $\mathrm{PAO}$ pili) & $15 \cdot 8$ & $15 \cdot 0$ & $17 \cdot 8$ & Paranchych et al. (1979) \\
\hline Spirillum serpens & 6.8 & 6.7 & 6.4 & Martinez et al. (1967) \\
\hline $\begin{array}{l}\text { Caulohacter crescentus CB } 15 \\
\text { (flagellins A plus B) }\end{array}$ & $11 \cdot 59$ & $12 \cdot 08$ & $15 \cdot 68$ & Sheffery \& Newton (1979) \\
\hline $\begin{array}{l}\text { Caulobacter crescentus PCM } 103 \\
\text { (polyhooks) }\end{array}$ & $11 \cdot 09$ & $10 \cdot 52$ & $11 \cdot 39$ & Sheffery \& Newton (1979) \\
\hline Vibrio anguillarum ${ }^{*}$ & $14 \cdot 28$ & $13 \cdot 7$ & 9.97 & Shinoda et al. (1976) \\
\hline Vibrio parahaemolyticus WP-1* & $15 \cdot 2$ & $15 \cdot 2$ & 14.4 & Shinoda et al. (1976) \\
\hline Beneckea neptuna* & $14 \cdot 7$ & 14.9 & 13.4 & Shinoda et al. (1976) \\
\hline $\begin{array}{l}\text { Rhizobium lupini } \mathrm{H} 13-3 \\
\text { (complex flagella) }\end{array}$ & $10 \cdot 12$ & $9 \cdot 26$ & $11 \cdot 53$ & Maruyama et al. (1978) \\
\hline Proteus rulgaris $\mathrm{P}$. & 13.4 & $12 \cdot 2$ & $9 \cdot 9$ & Kobayaishi et al. (1959) \\
\hline Proteus iulgaris IFO 5988 & $14 \cdot 6$ & $13 \cdot 0$ & $9 \cdot 7$ & Kurado (1972) \\
\hline Proteus mirahilis & 16.69 & $14 \cdot 79$ & $12 \cdot 67$ & Schalch \& Bode (1975) \\
\hline $\begin{array}{l}\text { Salmonella typhimurium } \\
\text { SW } 106 \text { la }\end{array}$ & $10 \cdot 5$ & $10 \cdot 1$ & $10 \cdot 9$ & Ambler \& Rees (1959) \\
\hline $\begin{array}{l}\text { Salmonella typhimurium } \\
\mathrm{SW} 106 \mathrm{~b} b\end{array}$ & $10 \cdot 4$ & $10 \cdot 3$ & $10 \cdot 5$ & McDonough (1965) \\
\hline Salmonella adelaide SW 1338 & $11 \cdot 2$ & $10 \cdot 9$ & $10 \cdot 1$ & Ada et al. (1964) \\
\hline Bacillus subtilis $\mathrm{SB} 19$ & $17 \cdot 3$ & $15 \cdot 2$ & $14 \cdot 3$ & Martinez et al. (1967) \\
\hline Bacillus subtilis 168 Group 1 & $18 \cdot 5$ & $15 \cdot 8$ & $14 \cdot 2$ & Simon et al. (1977) \\
\hline Bacillus subtilis 10783 Group 2 & $18 \cdot 1$ & $16 \cdot 9$ & $14 \cdot 4$ & Simon et al. (1977) \\
\hline Bacillus subtilis 9799 Group 3 & $15 \cdot 7$ & $15 \cdot 2$ & 16.9 & Simon et al. (1977) \\
\hline Bacillus subtilis 10774 Group 4 & $17 \cdot 6$ & $15 \cdot \overline{7}$ & $16 \cdot 6$ & Simon et al. (1977) \\
\hline Bacillus firmus RAB & $19 \cdot 2$ & $20 \cdot 0$ & $19 \cdot 5$ & Guffanti \& Eisenstein (1983) \\
\hline
\end{tabular}

We now appreciate that even highly purified flagellins may have more than one protein component, e.g. Caulobacter spp. which possess a 23-25000 and a $28000 \mathrm{~mol}$. wt flagellin (Lagenaur \& Agabian, 1977; Sheffery \& Newton, 1979; Gill \& Agabian, 1982; Johnson et al., 1983). Rhizobium lupini H13-3 has a cylindrical core of 43000 mol. wt flagellin surrounded by three bands forming a sheath of a $55000 \mathrm{~mol}$. wt flagellin monomer (Schmitt et al., 1974a; Maruyama et al., 1978), and similar complex flagella with 37000 and $55000 \mathrm{~mol}$. wt proteins were also reported for Pseudomonas rhodos (Schmitt et al., 1974b), although this 'unusual Pseudomonas' is now reclassified as a Protomonas, a new genus of facultatively methylotrophic bacteria (Urakami et al., 1984).

Our literature search for data shown in Table 6 also revealed a range of flagellin molecular weight values of 17-20000 for Proteus vulgaris (Erlander et al., 1960), Serratia marcescens and Bacillus subtilis (Kobayaishi et al., 1959); 33-40000 for 10 strains of B. subtilis (Simon et al., 1977); 40000 for B. firmus RAB (Guffanti \& Eisenstein, 1983); 30-50000 for other Bacillus spp. (DeLange et al., 1976); 40000 for unsheathed flagellins of Vibrio parahaemolyticus, $V$. anguillarum and Beneckea neptunea (Shinoda et al., 1976); 40000 for Proteus mirabilis (Schalch \& Bode, 1975); 45000 for flagellar cores of $V$. cholerae (Young et al., 1977); 54000 for Escherichia coli (Simon et al., 1978); 55000 for Salmonella (Ikeda et al., 1983); 56000 for Salmonella SJ25 (Kagawa et al., 1976), and 62000 (and a minor 87000 protein) for the purified flagellins of Campylobacter jejuni (Newell et al., 1984). Further literature revealed that flagella hook proteins were more homogeneous, ranging from 43000 to 40000 ; Homma et al. (1984) confirmed a value of 40000 for the hook proteins of several mutants of Salmonella typhimurium, but despite the fact 
that the values of approx. 40000 for our Pseudomonas flagellins fall within that commonly reported for hook proteins, we confirmed a definite filament location for our purified flagellins by direct immunofluorescent serology.

The gross amino acid composition of our three Pseudomonas flagellins (Table 3) is typical of prokaryotic flagella. The similarities in amino acid composition between the flagellins of the three type strains of Pseudomonas and other prokaryotes (including some data for purified pili and hooks) are shown in Table 6 in terms of 'difference index' (DI) values, as advocated by Metzger et al. (1968). The mol fraction per $40000 \mathrm{~mol}$. wt protein is used as a standard for comparing differences in the fractional content of each amino acid in the flagellin. The sum of the differences (irrespective of sign) is multiplied by 50 . On this scale, two proteins with no amino acids in common have a DI value of 100 and identical proteins have a zero value. Table 6 shows that the three Pseudomonas spp. and Spirillum serpens flagellins form a distinct, closelyrelated group. However, our calculations suggest that the DI values cannot be interpreted too finely because two $P$. aeruginosa pilins have different values, although they were virtually identical both chemically and physically (X-ray fibre diffraction patterns) according to Paranchych et al. (1979). Different DI values for five strains of Bacillus subtilis or the two strains of Proteus vulgaris (Table 6), confirm this conclusion.

Flagellin cores of polarly monotrichate Vibrio and Caulobacter are unexpectedly more similar to the flagellins of peritrichate Gram-negative rods (Rhizobium, Proteus and Salmonella) than they are to polarly flagellate Pseudomonas and Spirillum (Table 6). There is however a marked difference (see Table 6) between the Gram-positive Bacillus flagellins and all the other organisms analysed here. Thus the Gram-associated difference in the flagella seems greater than the positional polar-peritrichate difference; this was confirmed in a few test calculations which again revealed higher DI values between peritrichate Bacillus and either Proteus or Salmonella flagellins, compared with DI values for Gram-negative polar flagellins matched against peritrichate flagellins, as shown in Table 6.

Differences in DI values are unlikely to correlate with antigenic specificity [as indeed was found by Kurado (1972) for Salmonella and Escherichia flagellins] because Yamaguchi \& Iino (1969) found that even a single amino acid replacement may markedly change the entire antigenic pattern of the flagellum, whereas other single replacements resulted in only very small changes in antigenicity. The relationships between antigenic specificity and flagellin peptide patterns are fully discussed by Emerson \& Simon (1971) and Simon et al. (1977) for Bacillus subtilis.

Antisera produced against the three Pseudomonas flagellins prepared here showed no crossreactivity over a wide range of other Pseudomonas spp. (Table 5) and thus appeared to be species-specific. Each of the flagellin antisera however, did not react with either the sheared flagella or the flagellins of all strains of that species; this was disappointing for diagnostic purposes. Thus the flagella show sub-specific differences, a situation which is also reflected in the many attempts to differentiate $P$. aeruginosa serologically on the basis of thermolabile flagellar antigens (see Ansorg, 1978; Lányi \& Bergan, 1978). Pitt $(1981 a, b)$ describes his eventually successful flagellar (H) serotyping of all except 52 out of 823 clinical strains of $P$. aeruginosa into $22 \mathrm{H}$-typing patterns, involving $6 \mathrm{H}$ factors either singly or in various combinations. Thus his complex results confirm the genetic data now in the literature, and the findings reported here, which show that even the single polar flagellum of $P$. aeruginosa, or its purified flagellin, is a far from homogeneous entity, although our $P$. aeruginosa flagellin antiserum did not cross-react with any other Pseudomonas species tested here. Our results neither support nor negate the 'stabilized mutant' hypothesis to account for monotrichate $P$. aeruginosa and multitrichate $P$. fluorescens in phylogenetic terms, despite the laboratory induction of polarly multiflagellate mutants of $P$. aeruginos $a$ as reported by Suzuki \& Iino (1980). This apparently involved a single mutation, the mutation site(s) being linked to a fla cluster: for details of the genetic analysis of the flagellar genes in $P$. aeruginosa Tsuda \& Iino $(1983 a, b)$ may be consulted. No biochemical or serological properties of the parent or mutant flagella of $P$. aeruginosa were described by Suzuki \& Iino (1980); this would be of interest, as would also the converse experiment, i.e. the induction of stable monotrichate cells of $P$. fluorescens or $P$. putida. 
We should like to thank Dr L. Rogers for his assistance with the ultracentrifugation experiments, Dr W. A. Weetman for the amino acid analyses, and Dr M. B. McIllmurray and the Wellcome Research Laboratories for the gifts of the antisera. We are grateful to Dr D. E. Kell for his critical reading of the manuscript, and the support of a University of Wales Research Assistantship is also acknowledged.

\section{REFERENCES}

Ada, G. L., Nossall, G. J. V., Pye, J. \& Abbott, A. (1964). Antigens in immunity. I: Preparation and properties of flagella antigens from Salmonella adelaide. Australian Journal of Experimental Biology and Medical Science 42, 267-282.

Ambler, R. P. \& ReEs, M. W. (1959). \&-N-Methyl lysine in bacterial flagellar protein. Nature, London 184, 56-57.

ANSORG, R. (1978). Flagellaspezifisches H-Antigenschema von Pseudomonas aeruginosa. Zentralblatt für Bakteriologie, Parasitenkunde, Infektionskrankheiten und Hygiene (Abteilung I) A242, 228-238.

Carver, M., Joseph, F. \& Brown, F. C. (1953). An arginine histochemical method using Sakaguchi's new reagent. Stain Technology 28, 89-91.

CHART, H. (1983). Multiflagellate variants of Vibrio anguillarum. Journal of General Microbiology 129, 2193-2197.

Delange, R. J. Chang, J. W., Shaper, J. H. \& Glazer, A. N. (1976). Amino acid sequence of flagellin of Bacillus subtilis 168. Journal of Biological Chemistry 251, 705-711.

EmERSON, S. U. \& Simon, M. I. (1971). Variation in the primary structure of Bacillus subtilis flagellins. Journal of Bacteriology 106, 949-954.

ENomoto, M. \& IINo, T. (1966). Comparison of normal and curly flagella in $S$. abortus-equi by two-dimensional separation of peptides. Japanese Journal of Genetics 44, 131-139.

ERlander, S. R., Koffler, H. \& Foster, J. F. (1960). Physical properties of Proteus vulgaris flagellin. Archices of Biochemistry and Biophysics 90, 139-153.

Gerngross, O., Voss, K. \& Herfield, H. (1933). As cited in Feigl F. (1960). Spot Tests in Organic Analysis, 6th edn. Amsterdam: Elsevier Publishing Company.

Gill, P. R. \& Agabian, N. (1982). A comparative structural analysis of the flagellin monomers of Caulobacter crescentus indicates that these proteins are encoded by two genes. Journal of Bacteriology 150, 925-933.

Guffanti, A. A. \& Eisenstein, H. C. (1983). Purification and characterization of flagella from the alkalophile Bacillus firmus RAB. Journal of General Microbiology' 129, 3239--3242.

Holder, I. A., WheEler, R. \& Montie, T. C. (1982). Flagellar preparations from $P$ seudomonas aeruginosa: animal protection studies. Infection and Immunity 35 , 276-280.

Homma, M., Kutsukake, K., IINo, T. \& YamaGuchi, S. (1984). Hook-associated proteins essential for flagellar filament formation in Salmonella typhimurium. Journal of Bacteriology 157, 100-108.

Hopkins, F. G. \& Cole, S. W. (1901). Detection of tryptophan. Journal of Physiology 27, 427.

IKedA, T., KamiYa, R. \& Yamaguchi, S. (1983). Excretion of flagellin by a short-flagella mutant of Salmonella typhimurium. Journal of Bacteriology 153, 506-510.
IKeda, T., KamiYa, R. \& Yamaguchi, S. (1984). In vitro polymerization by a short-flagellum Salmonella typhimurium mutant. Journal of Bacteriology 159 , 787-789.

Jessen, O. (1965). Pseudomonas aeruginosa and other Green Fluorescent Pseudomonads: A Taxonomic Study. Copenhagen: Munksgaard.

Johnson, R. C., Ferber, D. M. \& Ely, B. (1983). Synthesis and assembly of flagellar components by Caulohacter crescentus motility mutants. Journal of Bacteriology 154, 1137-1144.

Kagawa, H. OWaribe, K., Asakura, S. \& Takahashi, N. (1976). Flagellar hook protein from Salmonella SJ25. Journal of Bacteriology 125, 68-73.

Kelman, A. \& HruschKa, J. (1973). The role of motility and aerotaxis in the selective increase of avirulent bacteria in still broth cultures of Pseudomonas solanacearum. Journal of General Microbiology 76, $177-188$.

KING, E. J. (1932). The colorimetric determination of phosphorus. Biochemical Journal 26, 292-297.

Kobayaishi, T., Rinker, J. N. \& Koffler, H. (1959). Purification and chemical properties of flagellin. Archives of Biochemistry and Biophysics 84, 342-362.

Kurado, H. (1972). Polymerisation of Salmonella, Proteus and Bacillus flagellins in citro. Biochimica et biophysica acta 285, 253-267.

Lagenaur, C. \& Agabian, N. (1977). Caulobacter flagellins. Journal of Bacteriology 132, 731-733.

LÁNYI, B. (1970). Serological properties of Pseudomonas aeruginosa. II. Type-specific thermolabile (flagellar) antigens. Acta microbiologica Academiae scientarum hungaricae 17, 35-48.

LÁNYI, J. \& BERGAN, T. (1978). Serological characterization of Pseudomonas aeruginosa. Methods in Microbiology 10, 93-168.

LOWRY, J. \& HANSON, J. (1965). Electron microscope studies of bacterial flagella. Journal of Molecular Biology 11, 293-313.

MCDonough, M. W. (1965). Amino acid composition of antigenically distinct Salmonella flagella proteins. Journal of Molecular Biology 12, 342-355.

MANN, T. \& LEONE, E. (1953). Studies on the metabolism of semen. 8. Ergothionene as a normal constituent of boar seminal plasma. Purification and crystallization. Site of formation and function. Biochemical Journal 53, 140-148.

Martinez, R. J., Brown, D. M. \& Glazer, A. N. (1967). The formation of bacterial flagella. III: Characterization of flagella from $B$. subtilis and $S$. serpens. Journal of Molecular Biology 28, 45-51.

Maruyama, M., Lodderstaedt, G. \& Schmitt, R. (1978). Purification and biochemical properties of complex flagella isolated from Rhizobium lupini H13-3. Biochimica et biophysica acta 535, 110-124.

Metzger, H., Shapiro, M. B., Mosimann, J. E. \& VINTON, J. E. (1968). Assessment of compositional relatedness between proteins. Nature, London 219 , 1166-1168. 
Miles, A. A., MisRa, S. S. \& Irwin, J. O. (1938). The estimation of the bactericidal power of the blood. Journal of Hygiene 38, 732-749.

Montie, T. C., Craven, R. C. \& Holder, I. A. (1982). Flagellar preparations from Pseudomonas aeruginosa: isolation and characterization. Infection and Immunity 35, 281-288.

Newell, D. G., McBride, H. \& Pearson, A. D. (1984). The identification of outer membrane proteins and flagella of Camplyobacter jejuni. Journal of General Microbiology 130, 1201-1208.

Panapoulos, N. J. \& SChroth, M. N. (1974). Role of flagellar motility in the invasion of bean leaves by Pseudomonas phaseolicola. Phytopathology 64, 13891397.

Paranchych, W., Sastry, P. A., Frost, L. S., Carpenter, M., Armstrong, G. D. \& Watts, T. H. (1979). Biochemical studies on pili isolated from Pseudomonas aeruginosa strain PAO. Canadian Journal of Microbiology 25, 1175-1181.

PITT, T. L. (1981a). Preparation of agglutinating antisera specific for the flagellar antigens of Pseudomonas aeruginosa. Journal of Medical Microbiology 14, 261-270.

PITT, T. L. (1981 b). A comparison of flagellar typing and phage typing as means of subdividing the $\mathbf{O}$ groups of Pseudomonas aeruginosa. Journal of Medical Microbiology 14, 261-270.

Rhodes, M. E. (1958). The cytology of Pseudomonas spp. as revealed by a silver-plating staining method. Journal of General Microbiology 18, 639-648.

Rowbury, R. J., Armitage, J. P. \& King, C. (1983). Movement, taxes and cellular interactions in the response of microorganisms to the natural environment. In Microbes in Their Natural Environments, pp. 299-350. Edited by J. H. Slater, R. Whittenbury \& J. W. T. Wimpenny. Cambridge: Cambridge University Press.

SCHALCH, W. \& BoDE, W. (1975). Involvement of tyrosine residues in the protomer-protomer interaction of Proteus mirabilis flagella as studied by spectroscopic methods, chemical modification and aggregation experiments. Biochimica et biophysica acta 405, 292-305.

SChmitt, R., Bamberger, I., ACKer, G. \& Mayer, F. $(1974 a)$. Feinstrukturanalyse der komplexen Geisseln von Rhizobium lupini H13-3. Archiv für Mikrobiologie 100, 145-162.

SChmitt, R., RASKa, I. \& MAYer, F. (1974b). Plain and complex flagella of Pseudomonas rhodos: analysis of fine structure and composition. Journal of Bacteriolog. 117, 844-857.

Shapiro, A. L., Viñuela, E. \& Maizel, J. V. (1967). Molecular weight estimation of polypeptide chains by electrophoresis in SDS-polyacrylamide gels. Biochemical and Biophysical Research Communications 28, 815-820.

Sheffery, M. \& Newton, A. (1979). Purification and characterization of a polyhook protein from Caulo- bacter crescentus. Journal of Bacteriology 138, 575583.

Shinoda, S., Kariyama, R., Ogawa, M., Takeda, Y. \& MiWATANI, T. (1976). Flagellar antigens of various species of the genus Vibrio and related genera. International Journal of Systematic Bacteriology 26, 97-101.

Simon, M. I., Emerson, S. U., Shaper, J. H., Bernard, P. D. \& Glazer, A. N. (1977). Classification of Bacillus subtilis flagellins. Journal of Bacteriology 130, 200-204.

Simon, M., Silverman, M., Matsumura, P., RidgeWAY, H., Komeda, Y. \& HiLmen, M. (1978). Structure and function of bacterial flagella. In Relations Between Structure and Function in the Prokaryotic Cell, pp. 271-283. Edited by R. Y. Stanier, H. J. Rogers \& B. J. Ward. Cambridge: Cambridge University Press.

Sneath, P. H. A. \& Collins, V. G. (1974). A study in test reproducibility between laboratories. Edited for the Pseudomonas Working Party by P. H. A. Sneath \& V. G. Collins. Antonie van Leeuwenhoek 40, 481527.

SNell, F. D. \& SNell, C. T. (1953). Colorimetric Methods of Analysis Including Some Turbidimetric and Nephelometric Methods, 3rd edn. New York: Van Nostrand.

Stanton, T. B. \& Savage, D. C. (1984). Motility as a factor in bowel colonization by Roseburia cecicola, an obligately anaerobic bacterium from the mouse caecum. Journal of General Microbiology 130, 173183.

Suzuki, T. \& IINo, T. (1980). Isolation and characterization of multiflagellate mutants of Pseudomonas aeruginosa. Journal of Bacteriology 143, 1471-1479.

TsudA, M. \& IINO, T. (1983a). Transductional analysis of the flagellar genes in Pseudomonas aeruginosa. Journal of Bacteriology 153, 1018-1026.

TsudA, M. \& IINO, T. (1983b). Ordering of the flagellar genes in Pseudomonas aeruginosa by insertions of mercury transposon Tn 501. Journal of Bacteriology 153, 1008-1017.

Urakami, T. \& Komagata, K. (1984). Protomonas, a new genus of facultatively methylotrophic bacteria. International Journal of Systematic Bacteriology 34, 188-201.

W AlKer, P. D., BatTy, I. \& Thomson, R. O. (1971). The localization of bacterial antigens by the use of fluorescent and ferritin labelled antibody techniques. Methods in Microbiology 5A, 219-247.

Weibull, C. (1948). Some chemical and physicochemical properties of the flagella of Proteus vulgaris. Biochimica et biophysica acta 2, 351-361.

YamaGUCHI, S. \& IINO, T. (1969). Genetic determination of the antigenic specificity of flagellar protein in Salmonella. Journal of General Microbiology 55, 9-74.

Young, G. C. H., Shrack, G. K. \& Freeman, B. A. (1977). Purification of flagellar cores of Vibrio cholerae. Journal of Bacteriology 129, 1121-1128. 